\title{
Polyphenols and dietary antioxidant potential, and their relationship with arterial hypertension: A cross-sectional study of the adult population in Poland (WOBASZ II)
}

\author{
Anna Waśkiewicz ${ }^{1, A-F}$, Małgorzata Elżbieta Zujkoo 2,A,C,E,F, Danuta Szcześniewska, ${ }^{1, B, C, F}$, \\ Andrzej Tykarski ${ }^{3, B, E, F}$, Magdalena Kwaśniewska ${ }^{4, B, E, F}$, Wojciech Drygas ${ }^{4,1, B, E, F}$, Anna Maria Witkowska ${ }^{2, A, C, E, F}$ \\ ${ }^{1}$ Department of Epidemiology, Cardiovascular Disease Prevention and Health Promotion, National Institute of Cardiology, Warszawa, Poland \\ 2 Department of Food Biotechnology, Medical University of Bialystok, Poland \\ ${ }^{3}$ Department of Hypertension, Angiology and Internal Medicine, Poznan University of Medical Sciences, Poland \\ ${ }^{4}$ Department of Social and Preventive Medicine, Medical University of Lodz, Poland \\ A - research concept and design; $\mathrm{B}$ - collection and/or assembly of data; $\mathrm{C}$ - data analysis and interpretation; \\ $D$ - writing the article; $E$ - critical revision of the article; $F$ - final approval of the article
}

Address for correspondence

Anna Waśkiewicz

E-mail: awaskiewicz@ikard.pl

\section{Funding sources}

This study was supported by the National Institute of Cardiology (grant N $0.2 .17 / / / 16)$ and by the Medical University of Bialystok (grant No. N/ST/ZB/16/001/3317).

\section{Conflict of interest}

None declared

\section{Acknowledgements}

The authors express special thanks to the entire research team and collaborators from the field centers in the 16 voivodeships, and to all participants of the WOBASZ II study.

Received on November 23, 2017

Reviewed on January 30, 2018

Accepted on May 22, 2018

Published online on April 8, 2019

D0I

$10.17219 /$ acem/91487

\section{Copyright}

Copyright by Author(s)

This is an article distributed under the terms of the Creative Commons Attribution Non-Commercial License (http://creativecommons.org/licenses/by-nc-nd/4.0/)

\section{Abstract}

Background. Oxidative stress plays a key role in the development of most non-communicable diseases, including arterial hypertension (AH). Diet is the major source of exogenous antioxidants, which support the body in the elimination of excessive free radicals.

Objectives. To assess dietary total antioxidant potential (DTAP) and dietary polyphenol intake (DPI), and to determine the relationship between DTAP, DPI and hypertension in the Polish adult population; to indicate dietary sources of DTAP and DPI in participants with and without AH.

Material and methods. Within the frame of the National Multicenter Health Survey (WOBASZ II), a random sample of the whole Polish population aged 20 years and above was screened during the years 2013-2014. Dietary habits and blood pressure were assessed in 2,554 men and 3,136 women. Dietary total antioxidant potential and DPI were calculated according to the amount of food consumed by the participants combined with the antioxidant potential and polyphenol contents in foods.

Results. The mean DTAP was $12.36 \mathrm{mmol} / \mathrm{day}$ in men and $12.27 \mathrm{mmol} / \mathrm{day}$ in women, and DPI was $2069 \mathrm{mg} /$ day and $1989 \mathrm{mg} / \mathrm{day}$, respectively. The DTAP and DPI were associated with reduced odds of AH in the Polish population. After adjusting for confounding variables, higher DTAP (by $1 \mathrm{mmol} / \mathrm{day}$ ) had reduced odds of AH by 1.3\% in men and by 1.8\% in women and higher DPI (by $100 \mathrm{mg} / \mathrm{day}$ ) by 1.1\% and by $2.2 \%$, respectively. Regardless of sex and AH, the main sources of DTAP and DPI were beverages, especially coffee and tea (over 50\%), fruit (12-24\%) and vegetables (12-18\%).

Conclusions. The intake of food with high antioxidant potential and rich in polyphenols was associated, slightly but independently of other factors, with a lower chance of hypertension in the adult Polish population. Irrespective of sex and AH, coffee and tea were the basic dietary sources of the antioxidants.

Key words: arterial hypertension, polyphenols, Polish population, dietary antioxidant potential

\section{Cite as}

Waśkiewicz A, Zujko ME, Szcześniewska D, et al. Polyphenols and dietary antioxidant potential, and their relationship with arterial hypertension: A cross-sectional study of the adult population in Poland (WOBASZ II). Adv Clin Exp Med. 2019:28(6):797-806. doi:10.17219/acem/91487 
Oxidative stress plays a key role in the development of most non-communicable diseases, including circulatory disorders and arterial hypertension $(\mathrm{AH})$. It results from an imbalance between the action of free radicals and the antioxidant potential of the body. Diet is the major source of exogenous antioxidants, such as polyphenols, certain vitamins $(\mathrm{C}, \mathrm{E}, \beta$-carotene) and mineral components ( $\mathrm{Se}, \mathrm{Zn}, \mathrm{Fe}, \mathrm{Mn}, \mathrm{Cu}$ ) which support the body in the elimination of excessive free radicals through suitable enzymatic proteins. ${ }^{1,2}$

A proper dietary supply of antioxidants exerts a beneficial effect on the lipid metabolism and endothelial function, reduces $\mathrm{AH}$ and decreases platelet aggregation, as well as seals and enhances vascular walls, leading to improvement in the peripheral circulation. However, the cardioprotective effect of polyphenols is based not only on the destruction of free radicals but also involves anti-aggregative properties and the ability to modulate numerous enzymatic pathways. ${ }^{2-6}$

Up to now, neither recommended dietary antioxidant potential nor the total content of polyphenols that would exert a beneficial effect on health have been established in a daily food ration. However, publications are available on antioxidant potential and polyphenol intake in the diets of people living in various countries as well as on the relationship between these parameters and cardiovascular disease (CVD), mainly in terms of mortality risk and rate. ${ }^{7-15}$ At the same time, there are by far fewer reports concerning the relationship between antioxidant potential and polyphenol intake and AH. ${ }^{16-19}$ In Poland, AH is diagnosed in approx. $42.7 \%$ of adult inhabitants, posing a substantial health hazard and generating social and economic costs. ${ }^{20}$

Taking into consideration the high prevalence of $\mathrm{AH}$ and the fact that oxidative stress is one of its promoting factors, it seems essential to investigate the consumption of bioactive substances that exhibit antioxidant properties in the Polish population.

The study objective was to:

- assess dietary total antioxidant potential (DTAP) and dietary polyphenol intake (DPI) in the Polish population in correlation with socioeconomic and health-related factors.

- evaluate the relationship between DTAP, DPI and AH;

- indicate and assess the differentiation of dietary sources of DTAP and DPI in participants with and without hypertension.

\section{Material and methods}

\section{Study population}

The study population involved a random sample of Polish residents aged 20 and older, examined in the years 2013-2014, as part of the Multicenter National Population Health Examination Survey (WOBASZ II). The project was conducted by the Institute of Cardiology in Warszawa, Poland, in cooperation with 5 medical universities in Poland. A total of 15,120 people of both sexes were drawn from the Department of State Registry database run by the Ministry of Internal Affairs (PESEL register). The selection was made as a 3-stage sampling, stratified according to administrative units (voivodeships), type of urbanization (community size) and sex. This type of random sampling, as well as the sample size, allowed reliable assessment of dietary habits in the Polish population. Altogether, 6,170 respondents were recruited to the study, whereas reliable dietary recalls were obtained from 5,689 people (2,554 men and 3,135 women). The aims of WOBASZ II, its organization scheme, methodological details, methods of information collection, and measurements were presented in an earlier paper. ${ }^{21}$

\section{Arterial blood pressure}

The level of arterial blood pressure was measured using automatic devices UA-631 (A\&D Company Ltd, Japan), approved by the Association for the Advancement of Medical Instrumentation (Arlington, USA). Blood pressure was measured 3 times at the right shoulder, in a sitting position, at 1-minute intervals. The mean value of blood pressure obtained from the $2^{\text {nd }}$ and $3^{\text {rd }}$ measurements was taken for the assessment. Study participants were diagnosed with hypertension when their systolic blood pressure (SBP) was $\geq 140 \mathrm{~mm} \mathrm{Hg}$ and/or diastolic blood pressure (DBP) was $\geq 90 \mathrm{~mm} \mathrm{Hg}$, and/or they took hypotensive drugs. ${ }^{21}$

\section{Dietary assessment}

Dietary habits were assessed by means of a 24-hour dietary recall. The consumption of products that are the source of the antioxidant potential and polyphenols was calculated on the basis of daily food intake and food formulation. Food products were combined into groups, taking into consideration their type, origin and production technology. A total of 367 products and dishes, i.e., various beverages, vegetables and their products, fruit and jams, nuts and seeds, cereals, bread, and chocolate were included in the study.

\section{Determination of antioxidant potential and polyphenols in food}

The antioxidant potential and the content of polyphenols in food products typical of the Polish market were determined in the Department of Food Biotechnology, Medical University of Bialystok, Poland. The analyses involved 3 independent samples of each product, purchased in retail, and in each case 2 versions were taken into consideration - the raw product and the product after culinary process. The distinction between raw and after culinary processes 
is made due to the fact that culinary processes have an influence on investigated dietary antioxidants. ${ }^{22}$ Solid food samples were dried and extracted using a methanol-acetate mixture, and the extracts were analyzed. Direct measurements were performed in fluid samples. The antioxidant potential was determined using the ferric-reducing antioxidant potential (FRAP) method, according to Benzie and Strain, ${ }^{23}$ and the polyphenol content (expressed as aglycones) was measured using the method according to Singleton and Rossi. ${ }^{24}$ For each of the products, an average of 3 measurements was assumed for further analysis. In the case of the very few products that were not subjected to laboratory analysis, the antioxidant potential and polyphenol content were obtained from the available database. ${ }^{25,26}$ For each study participant, DTAP and DPI were determined taking into consideration the consumption of food products and the level of their antioxidant potential and polyphenol content.

\section{Statistical methods}

Methods of descriptive statistics were applied to describe continuous variables (mean, standard deviation (SD), quartiles) and the percentages of the respective values were used for categorized variables. Parametric tests (analysis of variance (ANOVA) and Student's t-test) and non-parametric tests (Mann-Whitney-Wilcoxon test and $X^{2}$ test) were used to compare the groups, depending on whether they fulfil the assumption of normal distribution or not.

The analysis of covariance (generalized linear model (GLM) procedure) with age and season adjustment was applied to determine the mean DTAP and DPI in groups with different socioeconomic and health status. The association between DTAP, DPI and AH was assessed by logistic regression analyses (LOGISTIC procedure). Odds ratios (ORs) with the corresponding 95\% confidence intervals (CIs) were calculated for unadjusted and adjusted models.

The level of significance for bilateral tests was considered to be at $\mathrm{p}<0.05$. The statistical analysis was performed with the statistical package SAS v. 9.2 (SAS Institute, Cary, USA).

\section{Results}

The mean total antioxidant potential of a daily food ration in the adult population of Poland (age- and seasonadjusted) was $12.36 \mathrm{mmol} /$ day in the group of men and $12.27 \mathrm{mmol} /$ day in the group of women, whereas the total content of polyphenols was found to be $2,069 \mathrm{mg} /$ day and $1,989 \mathrm{mg} /$ day, respectively (Table 1,2 ). The levels of the parameters studied depended on socioeconomic and health-related factors, such as age, marital status and paid employment in both sexes, and education only in women. Of the health-related factors, DTAP was determined by health self-assessment in both sexes, CVD in men and
$\mathrm{AH}$ in women. In turn, DPI in men was influenced by CVD, and in women by $\mathrm{AH}$, diabetes and health self-assessment (Table 1, 2).

The analysis of the relationship between DTAP, DPI and $\mathrm{AH}$, having eliminated other factors, showed a significant decrease in the contribution of women with $\mathrm{AH}$ along with an increase in the quartile of the antioxidant potential (45\% in $1^{\text {st }}$ quartile vs $38 \%$ in $4^{\text {th }}$ quartile) and polyphenols ( $45 \%$ vs $39 \%$, respectively). In the group of men, the tendencies were similar, although statistically insignificant (Table 3).

The odds of AH with the antioxidant potential increased by $1 \mathrm{mmol} /$ day was lower by $1.1 \%$ in the group of men and by $2.3 \%$ among women, and after adjustment for confounding variables (listed below Table 3 ), lower by $1.3 \%$ and $1.8 \%$, respectively, in the sex groups. Similar results were obtained for polyphenols. The increase in the polyphenol supply by $100 \mathrm{mg} /$ day, lowered the odds of AH by $0.8 \%$ in men and by $2.4 \%$ in women, and after adjustment for other AH-affecting factors, by $1.1 \%$ and $2.2 \%$, respectively (Table 4).

Tables 5 and 6 present the contribution of food groups (beverages, vegetables, fruit, cereals, nuts and seeds, chocolate, and cacao) to DTAP and DPI intakes. Among adult residents of Poland, irrespective of sex and $\mathrm{AH}$, beverages, especially tea and coffee, appeared to be the basic food sources of antioxidant potential and polyphenols. Over $50 \%$ of DTAP and more than $40 \%$ of DPI were obtained from beverages. Fruit provided approx. 12-18\% of the antioxidant potential and $17-24 \%$ of polyphenols, and vegetables $14-18 \%$ and $12-14 \%$, respectively, depending on sex and $\mathrm{AH}$. Further places were occupied by cereal products, nuts and seeds, chocolate, and cacao. Of fruit, apples and strawberries, and of vegetables, potatoes and cabbage were a significant source of DTAP and DPI, and beetroots of DTAP only.

Some differences were found in dietary sources of DTAP and DPI between people with and without AH. Among men with $\mathrm{AH}$, the contribution of DTAP and DPI from fruit was higher whereas from cereal products, nuts and seeds, chocolate and cacao, it was lower. The diet of women with AH was characterized by a lower contribution of DTAP and DPI obtained from beverages, cereal products, chocolate, and cacao. The quantities provided by vegetables and fruit were similar, irrespective of AH (Table 5, 6).

\section{Discussion}

The imbalance between pro- and antioxidant processes and the accumulation of reactive oxygen species (ROS) in the body which initiate cellular damage promote noncommunicable diseases. A significant correlation was found between the dietary antioxidant potential and the antioxidant status of blood serum. ${ }^{27}$ Thus, proper nutrition provided by dietary components which act as antioxidants can prevent the harmful effects of oxidative stress. 


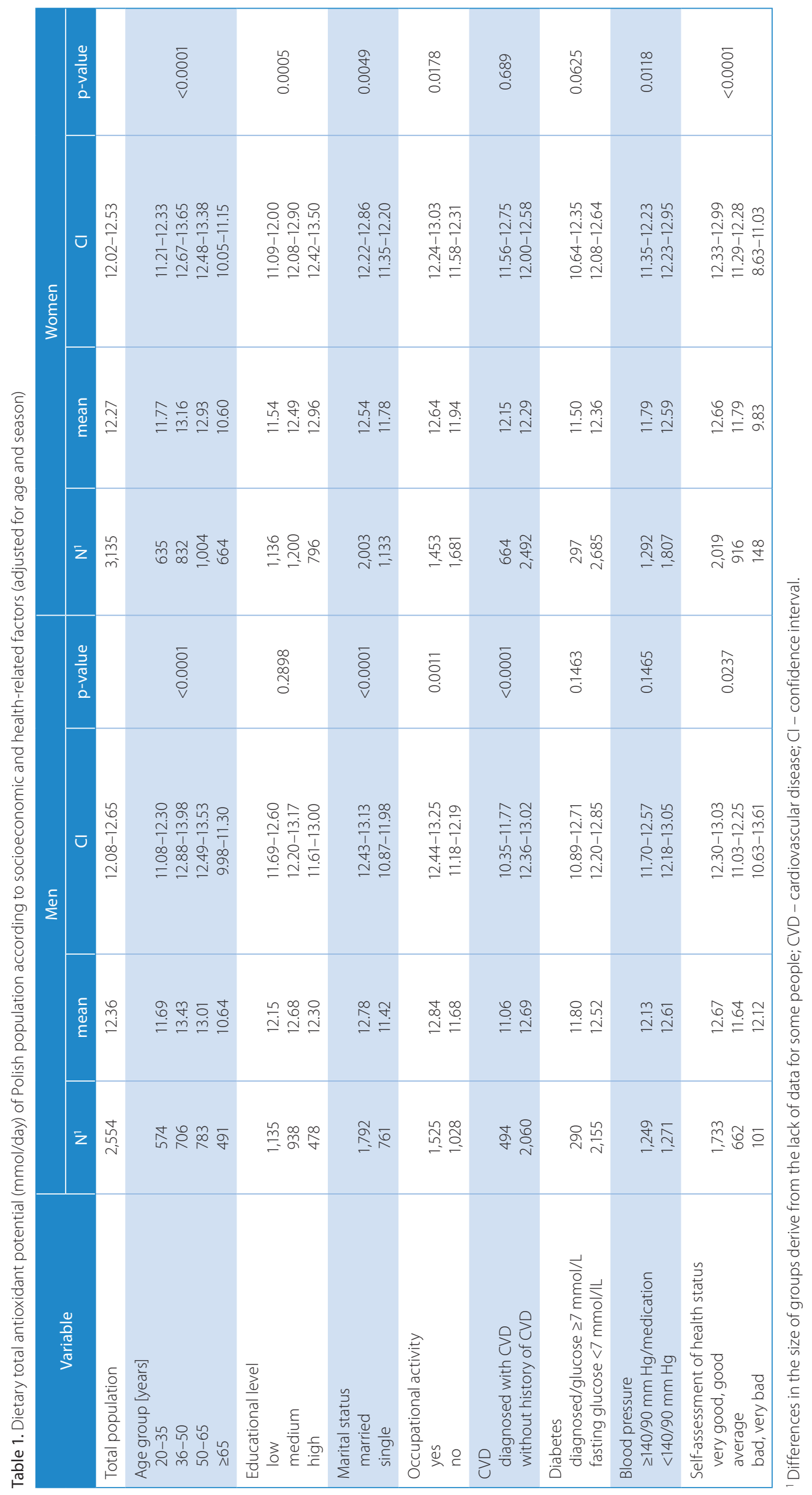




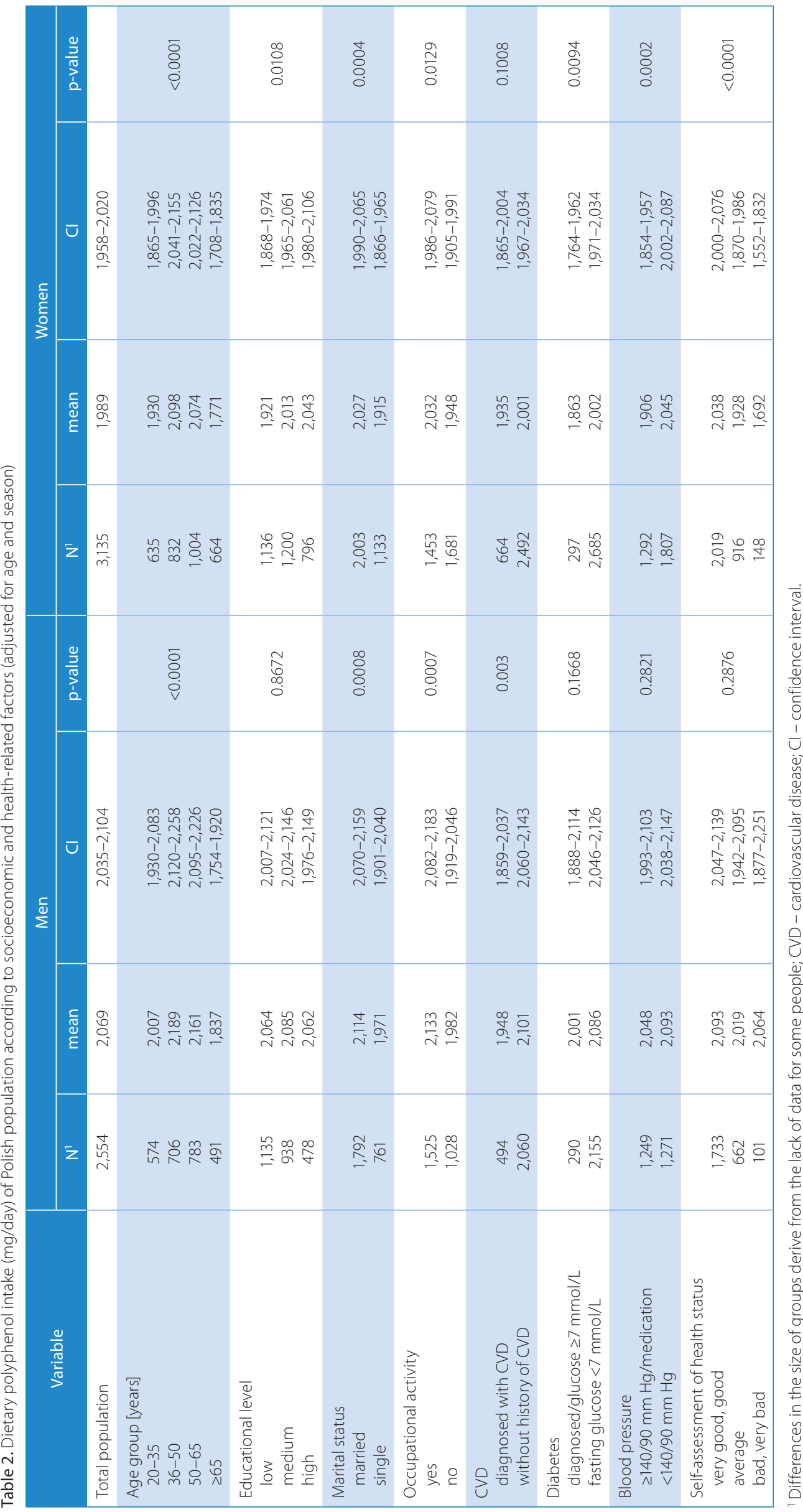


Table 3. Prevalence of arterial hypertension by quartiles of dietary total antioxidant potential (DTAP) and dietary polyphenol intake (DPI)

\begin{tabular}{|c|c|c|c|c|c|}
\hline Parameters & Quartile 1 & Quartile 2 & Quartile 3 & Quartile 4 & $p$-value \\
\hline \multicolumn{6}{|c|}{ Men } \\
\hline $\begin{array}{l}\text { DTAP }[\mathrm{mmol} / \mathrm{day}] \\
\text { mean } \pm \mathrm{SD} \\
\text { range }\end{array}$ & $\begin{array}{c}5.22 \pm 1.75 \\
0.47-7.70\end{array}$ & $\begin{array}{l}9.43 \pm 1.02 \\
7.71-11.15\end{array}$ & $\begin{array}{l}13.16 \pm 1.20 \\
11.16-15.38\end{array}$ & $\begin{array}{l}21.67 \pm 8.52 \\
15.39-95.37\end{array}$ & \\
\hline Arterial hypertension [\%] & 50.15 & 51.56 & 50.98 & 46.24 & 0.1489 \\
\hline $\begin{array}{l}\mathrm{DPI}[\mathrm{mg} / \text { day }] \\
\text { mean } \pm \mathrm{SD} \\
\text { range }\end{array}$ & $\begin{array}{c}1,033 \pm 285 \\
174-1,409\end{array}$ & $\begin{array}{l}1,694 \pm 158 \\
1,410-1,956\end{array}$ & $\begin{array}{l}2,252 \pm 173 \\
1,957-2,559\end{array}$ & $\begin{array}{l}3,305 \pm 800 \\
2,560-9,047\end{array}$ & \\
\hline Arterial hypertension [\%] & 49.64 & 50.91 & 51.91 & 46.42 & 0.1511 \\
\hline \multicolumn{6}{|c|}{ Women } \\
\hline $\begin{array}{l}\text { DTAP }[\mathrm{mmol} / \mathrm{day}] \\
\text { mean } \pm \mathrm{SD} \\
\text { range }\end{array}$ & $\begin{array}{c}5.52 \pm 1.77 \\
0.32-7.91\end{array}$ & $\begin{array}{l}9.72 \pm 1.00 \\
7.94-11.35\end{array}$ & $\begin{array}{c}13.14 \pm 1.11 \\
11.35-15.19\end{array}$ & $\begin{array}{c}20.68 \pm 9.07 \\
15.20-191.82\end{array}$ & \\
\hline Arterial hypertension [\%] & 45.17 & 42.88 & 41.11 & 38.12 & 0.0073 \\
\hline $\begin{array}{l}\mathrm{DPI}[\mathrm{mg} / \mathrm{day}] \\
\text { mean } \pm \mathrm{SD} \\
\text { range }\end{array}$ & $\begin{array}{c}1,035 \pm 273 \\
140-1,414\end{array}$ & $\begin{array}{l}1,665 \pm 138 \\
1,415-1,903\end{array}$ & $\begin{array}{c}2,156 \pm 155 \\
1,904-2,441\end{array}$ & $\begin{array}{c}3,093 \pm 703 \\
2,442-8,793\end{array}$ & \\
\hline Arterial hypertension [\%] & 45.37 & 43.68 & 39.40 & 38.82 & 0.0030 \\
\hline
\end{tabular}

Adjusted for age, BMI, smoking and physical activity; BMI - body mass index; SD - standard deviation.

Table 4. Multivariate odds ratio (OR) and 95\% confidence intervals (95\% CI) for arterial hypertension by total dietary total antioxidant potential (DTAP) (per $1 \mathrm{mmol} /$ day) and dietary polyphenol intake (DPI) (per $100 \mathrm{mg} / \mathrm{day}$ )

\begin{tabular}{|c|c|c|c|c|c|c|}
\hline \multirow{2}{*}{ Variables } & \multicolumn{3}{|c|}{ Men } & \multicolumn{3}{|c|}{ Women } \\
\hline & OR & $95 \% \mathrm{Cl}$ & $\mathrm{p}$-value & OR & $95 \% \mathrm{Cl}$ & $p$-value \\
\hline $\begin{array}{l}\text { DTAP } \\
\text { unadjusted } \\
\text { adjusted }^{1}\end{array}$ & $\begin{array}{l}0.989 \\
0.987\end{array}$ & $\begin{array}{l}0.979-0.999 \\
0.976-0.998\end{array}$ & $\begin{array}{l}0.0480 \\
0.0248\end{array}$ & $\begin{array}{l}0.977 \\
0.982\end{array}$ & $\begin{array}{l}0.966-0.988 \\
0.970-0.995\end{array}$ & $\begin{array}{c}<0.0001 \\
0.0051\end{array}$ \\
\hline $\begin{array}{l}\text { DPI } \\
\text { unadjusted } \\
\text { adjusted }^{1}\end{array}$ & $\begin{array}{l}0.992 \\
0.989\end{array}$ & $\begin{array}{l}0.983-0.999 \\
0.981-0.998\end{array}$ & $\begin{array}{l}0.0474 \\
0.0194\end{array}$ & $\begin{array}{l}0.976 \\
0.978\end{array}$ & $\begin{array}{l}0.967-0.985 \\
0.969-0.988\end{array}$ & $\begin{array}{l}<0.0001 \\
<0.0001\end{array}$ \\
\hline
\end{tabular}

${ }^{1}$ Adjusted for age, body mass index (BMI), smoking and physical activity.

The results indicate that the mean total antioxidant potential in the diet of the adult Polish population was $12.36 \mathrm{mmol} /$ day in the group of men and $12.27 \mathrm{mmol} /$ day in the group of women, whereas the polyphenol content amounted to $2,069 \mathrm{mg} /$ day and 1,989 $\mathrm{mg}$ /day, respectively. However, the comparison of our results with the levels of DTAP and DPI in other populations is very difficult due to, first of all, the use of various methods to determine these substances. The antioxidant potential can be measured, e.g., according to the FRAP or oxygen radical absorbance capacity (ORAC) method. The polyphenols exist as aglycones (the free form) or glycosides (occurring as compounds with sugars, most commonly with glucose).

Since the recommended level of DTAP and DPI has not been established, it is difficult to assess whether the intake of bioactive components of adult residents of Poland meets recommendations.

There are very few studies, particularly conducted in Polish centers, the results of which can be directly compared to our findings. The available data obtained with the ORAC method indicates that DTAP was found at the level of 8,300-10,000 $\mu$ molTE/day among the population of Wrocław, Poland. ${ }^{11,14}$ Similar results were noted in the European Prospective Investigation into Cancer and Nutrition (EPIC) project, in which DTAP in the Spanish and Greek population was in the range of 11,000-12,000 $\mu \mathrm{molTE} /$ day. ${ }^{8,9}$ In women living in Sweden, DTAP amounted to $12,127 \mu \mathrm{molTE} /$ day. ${ }^{7}$ All these values were consistent with the recommendations of Priori et al., ${ }^{28}$ who were the only investigators to assess that DTAP has to be at the level of 3,000-5,000 $\mu$ molTE/day to ensure the proper antioxidant capacity of tissues and blood.

In the male population of Sweden, DTAP determined with the FRAP method was approx. $22 \mathrm{mmol} /$ day, and was higher by over $60 \%$ than in the Polish population. ${ }^{29}$

The mean estimates of the intake of polyphenols (approx. $2,000 \mathrm{mg} /$ person/day) were comparable to those reported from Kraków, Poland (1,757 mg), ${ }^{15}$ but higher than in Finland (863 mg), ${ }^{13}$ Japan $(1,492 \mathrm{mg}),{ }^{12}$ France $(1,193 \mathrm{mg}),{ }^{30}$ and Spain $(820 \mathrm{mg}){ }^{10}$

However, irrespective of the consumption volume, dietary sources of DTAP and DPI differed between the respective countries. The intake of antioxidants in the Polish 
Table 5. Contributions of food categories to dietary total antioxidant potential (DTAP) in persons with and without arterial hypertension (AH)

\begin{tabular}{|c|c|c|c|}
\hline \multicolumn{4}{|c|}{ Men } \\
\hline Food categories & with $\mathrm{AH}(\mathrm{N}=1,249)$ & without $\mathrm{AH}(\mathrm{N}=1,271)$ & $p$-value \\
\hline Beverages & $\begin{array}{c}6.52 \mathrm{mmol} / \text { day }(54.0 \%) \text { : coffee }(27.8 \%) ; \text { tea }(22.7 \%) ; \\
\text { alcohol (1.6\%) }\end{array}$ & $\begin{array}{l}6.90 \mathrm{mmol} / \mathrm{day}(54.5 \%) \text { : coffee (30.9\%); tea (20.1\%); } \\
\text { alcohol (1.4\%) }\end{array}$ & 0.1271 \\
\hline Vegetables & $\begin{array}{c}2.20 \mathrm{mmol} / \text { day }(18.2 \%) \text { : potato }(7.1 \%) ; \text { beetroot }(3.0 \%) ; \\
\text { cabbage (2.2\%); tomato }(1.2 \%) ; \text { broccoli and } \\
\text { cauliflower }(1.1 \%)\end{array}$ & $\begin{array}{c}2.25 \mathrm{mmol} / \text { day }(17.8 \%) \text { : potato }(6.6 \%) \text {; beetroot }(3.6 \%) ; \\
\text { cabbage ( } 2.2 \%) ; \text { tomato }(1.1 \%) ; \text { broccoli and } \\
\text { cauliflower }(0.9 \%)\end{array}$ & 0.9603 \\
\hline Fruit & $\begin{array}{c}1.85 \mathrm{mmol} / \text { day }(15.3 \%) \text { : apples }(4.8 \%) ; \\
\text { strawberries (2.1\%); grapes (1.7\%); plums (1.4\%); citrus } \\
\text { fruits }(0.8 \%) ; \text { cherries }(0.8 \%)\end{array}$ & $\begin{array}{c}1.55 \mathrm{mmol} / \text { day }(12.2 \%) \text { : apples }(4.0 \%) ; \\
\text { strawberries ( } 1.3 \%) ; \text { grapes. }(1.1 \%) ; \text { plums }(0.9 \%) ; \text { citrus } \\
\text { fruits }(0.7 \%) ; \text { cherries }(0.8 \%)\end{array}$ & 0.0050 \\
\hline Cereals & $\begin{array}{c}0.56 \mathrm{mmol} / \text { day }(4.6 \%) \text { : mixed bread (1.9\%); wheat } \\
\text { bread (0.9\%); rye bread }(0.9 \%)\end{array}$ & $\begin{array}{c}0.61 \mathrm{mmol} / \text { day }(4.6 \%) \text { : mixed bread (1.9\%); wheat } \\
\text { bread (1.0\%); rye bread }(0.7 \%)\end{array}$ & 0.0002 \\
\hline Nuts and seeds & $0.32 \mathrm{mmol} /$ day (2.7\%) & 0.60 mmol/day (4.8\%) & 0.0295 \\
\hline Chocolate and cocoa & $0.29 \mathrm{mmol} /$ day (2.4\%) & $0.38 \mathrm{mmol} / \mathrm{day}(3.0 \%)$ & 0.0002 \\
\hline \multicolumn{4}{|c|}{ Women } \\
\hline Food categories & with $\mathrm{AH}(\mathrm{N}=1,292)$ & without $\mathrm{AH}(\mathrm{N}=1,807)$ & $p$-value \\
\hline Beverages & $\begin{array}{c}6.49 \mathrm{mmol} / \text { day (55.8\%): coffee (32.2\%); tea (22.0\%); } \\
\text { alcohol (0.2\%) }\end{array}$ & $\begin{array}{c}7.38 \mathrm{mmol} / \text { day (58.2\%): coffee (36.4\%); tea (19.4\%); } \\
\text { alcohol (0.3\%) }\end{array}$ & 0.0001 \\
\hline Vegetables & $\begin{array}{c}1.75 \mathrm{mmol} / \text { day }(15.0 \%) \text { : potato }(5.2 \%) ; \text { beetroot }(2.4 \%) ; \\
\text { cabbage (1.9\%); tomato ( } 1.2 \%) ; \text { broccoli and } \\
\text { cauliflower (1.1\%) }\end{array}$ & $\begin{array}{c}1.82 \mathrm{mmol} / \text { day }(14.4 \%) \text { : potato }(4.6 \%) \text {. beetroot }(2.8 \%) \text {. } \\
\text { cabbage (1.8\%). tomato (1.0\%). broccoli and } \\
\text { cauliflower }(1.2 \%)\end{array}$ & 0.4879 \\
\hline Fruit & $\begin{array}{l}2.12 \mathrm{mmol} / \text { day }(18.2 \%) \text { : apples (4.9\%); } \\
\text { strawberries (2.8\%); grapes. (2.2\%); plums (1.6\%); citrus } \\
\text { fruits (1.0\%) }\end{array}$ & $\begin{array}{l}1.98 \mathrm{mmol} / \text { day (15.6\%): apples (4.5\%); } \\
\text { strawberries (2.2\%); grapes. (1.7\%); plums (1.1\%); citrus } \\
\text { fruits (1.1\%) }\end{array}$ & 0.9210 \\
\hline Cereals & $\begin{array}{c}0.40 \mathrm{mmol} / \text { day }(3.4 \%) \text { : mixed bread }(1.0 \%) \text {; wheat } \\
\text { bread }(0.7 \%) \text {; rye bread }(0.7 \%)\end{array}$ & $\begin{array}{c}0.43 \mathrm{mmol} / \text { day }(3.4 \%) \text { : mixed bread }(0.9 \%) \text {; wheat } \\
\text { bread }(0.7 \%) \text {; rye bread }(0.7 \%)\end{array}$ & 0.0001 \\
\hline Nuts and seeds & 0.39 mmol/day (3.3\%) & 0.42 mmol/day (3.3\%) & 0.1207 \\
\hline Chocolate and cocoa & 0.24 mmol/day (2.1\%) & 0.36 mmol/day (2.8\%) & 0.0001 \\
\hline
\end{tabular}

Table 6. Contributions of food categories to dietary polyphenol intake (DPI) in persons with and without arterial hypertension (AH)

\begin{tabular}{|c|c|c|c|}
\hline \multicolumn{4}{|c|}{ Men } \\
\hline Food categories & with $\mathrm{AH}(\mathrm{N}=1,249)$ & without $\mathrm{AH}(\mathrm{N}=1,271)$ & $p$-value \\
\hline Beverages & $\begin{array}{c}818.0 \text { mg/day (40.2\%): coffee (18.8\%); tea (18.2\%); } \\
\text { alcohol (1.2\%) }\end{array}$ & $\begin{array}{c}860.0 \text { mg/day (40.8\%): coffee (22.3\%); tea (16.1\%); } \\
\text { alcohol (1.0\%) }\end{array}$ & 0.2013 \\
\hline Vegetables & $\begin{array}{c}288.2 \mathrm{mg} / \text { day }(14.2 \%) \text { : potato }(6.7 \%) ; \text { cabbage }(1.5 \%) ; \\
\text { tomato }(1.6 \%)\end{array}$ & $\begin{array}{c}293.2 \mathrm{mg} / \text { day }(13.9 \%) \text { : potato }(6.3 \%) ; \text { cabbage }(1.5 \%) \\
\text { tomato }(1.4 \%)\end{array}$ & 0.5790 \\
\hline Fruit & $\begin{array}{c}409.0 \text { mg/day (20.1\%): apples (10.2\%); plums (2.4\%); } \\
\text { strawberries (1.3\%); bananas (1.2\%); currant (0.9\%); } \\
\text { grapes (0.9\%) }\end{array}$ & $\begin{array}{c}359.5 \text { mg/day (17.1\%): apples (8.6\%); plums (1.5\%); } \\
\text { strawberries (0.8\%); bananas (1.7\%); currant (0.6\%); } \\
\text { grapes }(0.6 \%)\end{array}$ & 0.0010 \\
\hline Cereals & $\begin{array}{c}382.0 \mathrm{mg} / \text { day }(18.8 \%) \text { : mixed bread }(8.4 \%) \text {; wheat } \\
\text { bread (3.9\%); rye bread }(3.7 \%)\end{array}$ & $\begin{array}{c}415.8 \mathrm{mg} / \text { day }(19.7 \%) \text { : mixed bread }(8.5 \%) \text {; wheat } \\
\text { bread }(4.4 \%) \text {; rye bread }(3.1 \%)\end{array}$ & 0.003 \\
\hline Nuts and seeds & 16.0 mg/day (0.8\%) & 28.8 mg/day (1.4\%) & 0.0287 \\
\hline Chocolate and cocoa & 56.0 mg/day (2.7\%) & 74.5 mg/day (3.5\%) & 0.0002 \\
\hline \multicolumn{4}{|c|}{ Women } \\
\hline Food categories & with $\mathrm{AH}(\mathrm{N}=1,292)$ & without $\mathrm{AH}(\mathrm{N}=1,807)$ & $\mathrm{p}$-value \\
\hline Beverages & $\begin{array}{c}813.7 \text { mg/day (43.1\%): coffee (23.9\%); tea (18.1\%); } \\
\text { alcohol (0.1\%) }\end{array}$ & $\begin{array}{c}917.9 \text { mg/day (44.6\%): coffee (27.0\%). tea (16.0\%); } \\
\text { alcohol (0.2\%) }\end{array}$ & 0.0001 \\
\hline Vegetables & $\begin{array}{c}234.7 \mathrm{mg} / \text { day }(12.4 \%) \text { : potato }(5.1 \%) ; \text { cabbage }(1.2 \%) ; \\
\text { tomato }(1.6 \%)\end{array}$ & $\begin{array}{c}242.0 \mathrm{mg} / \text { day }(11.8 \%) \text { : potato }(4.5 \%) . \text { cabbage }(1.3 \%) \\
\text { tomato }(1.4 \%)\end{array}$ & 0.6405 \\
\hline Fruit & $\begin{array}{c}456.8 \text { mg/day (24.2\%): apples (10.8\%); plums (2.8\%); } \\
\text { strawberries (1.7\%); bananas (1.3\%); currant (1.2\%); } \\
\text { grapes (1.2\%); peaches (1.7\%) }\end{array}$ & $\begin{array}{l}440.6 \text { mg/day }(21.4 \%) \text { apples }(9.9 \%) ; \text { plums }(1.9 \%) ; \\
\text { strawberries (1.4\%); bananas }(2.0 \%) ; \text { currant }(2.0 \%) ; \\
\text { grapes }(0.9 \%) ; \text { peaches }(0.9 \%)\end{array}$ & 0.8030 \\
\hline Cereals & $\begin{array}{c}261.3 \mathrm{mg} / \text { day (13.8\%): mixed bread (4.7\%); wheat } \\
\text { bread (3.2\%); rye bread (3.1\%) }\end{array}$ & $\begin{array}{c}285.0 \mathrm{mg} / \text { day }(13.9 \%) \text { : mixed bread (4.1\%); wheat } \\
\text { bread (3.1\%); rye bread (3.0\%) }\end{array}$ & 0.0010 \\
\hline Nuts and seeds & 19.7 mg/day (1.0\%) & 22.3 mg/day (1.1\%) & 0.1193 \\
\hline Chocolate and cocoa & 47.3 mg/day (2.5\%) & 75.4 mg/day (3.7\%) & 0.0001 \\
\hline
\end{tabular}


population, noted both in the current research and previously, ${ }^{14,15,31}$ as well as in Japan ${ }^{12}$ was related mainly to the consumption of coffee and tea, and then vegetables and fruit, whereas in Finland it was related to the intake of coffee and cereal products, ${ }^{13}$ in Spain to coffee, fruit and olive oil, ${ }^{10}$ and in Sweden and Greece to vegetables and fruit., ${ }^{79}$ These results indicate a difference in the structure of dietary sources of DTAP and DPI between people with and without $\mathrm{AH}$. Respondents with $\mathrm{AH}$ showed lower consumption of coffee, alcohol, cereal products, chocolate, and cacao, and therefore of fewer bioactive substances derived from those products. Men with AH also consumed more fruit and fewer nuts and seeds. However, the cross-sectional character of the WOBASZ II does not allow for any cause-and-effect conclusions and it is therefore unknown whether their diet underwent modification due to the disease or the people with AH had these dietary habits earlier.

There has been a growing interest in the potential involvement of reactive oxygen forms in the search for $\mathrm{AH}$ causes. However, the metabolic mechanisms underlying this relationship still remain insufficiently explained, despite numerous studies. Obviously, the imbalance between free oxygen radicals and antioxidant factors (also from food) contributes to endothelial damage and enhances inflammatory reactions, which have been recently reported to be responsible for $\mathrm{AH} .{ }^{32}$

Observational and experimental studies confirm that diets with high antioxidant potential and high polyphenol content contribute to $\mathrm{AH}$ reduction. ${ }^{5,18}$ However, most of these projects assessed these correlations only at the level of the respective products rich in polyphenols (e.g., cacao, fruit and vegetables, tea, olive oil, etc.), ${ }^{1}$ and only few took into consideration total dietary antioxidant potential and total polyphenol intake.

The current results seem to prove a slight but independent relationship between the dietary antioxidants studied and $\mathrm{AH}$ among adult Polish residents. Even less advanced statistical analyses showed lower mean values of DTAP and DPI in women with AH than in those without this condition. A significant reduction was also noted in the involvement of women with AH along with the increased DTAP and DPI quartile, even after adjustment for confounding variables. The tendencies were similar in men, although statistically insignificant.

However, more advanced analyses revealed that with DTAP increased by $1 \mathrm{mmol} /$ day or DPI by $100 \mathrm{mg} /$ day, the odds of $\mathrm{AH}$ in both sexes decreased by approx. 1-2\%, even after correcting for confounding variables.

Our data is comparable to the results obtained in few studies which took into consideration total antioxidant activity and total dietary polyphenol intake. However, it should be added that in some of them the levels of biomarkers excreted with urine were referred to as the variables reflecting their dietary intake.

For instance, in São Paulo, Brazil, an inverse relation was observed between total polyphenol content and
$\mathrm{AH}$, but also with regard to the $2^{\text {nd }}$ quartile, $\mathrm{OR}=0.36$ $(\mathrm{CI}=0.19-0.69)$. Also, significant and linear correlations were noted between certain classes of polyphenols, such as tyrosols, alkylphenols, lignans, and stilbenes, which unfortunately were not evaluated in our study. ${ }^{16}$ However, in the PREvencion con DIeta MEDiterranea (PREDIMED) study it was estimated that in individuals with high risk of cardiovascular diseases, the risk of $\mathrm{AH}$ in the highest quartile of urinary polyphenols was $0.64(\mathrm{CI}=0.45-0.92)$, as compared to the lowest quartile, after eliminating other factors. Also, the values of SBP and DBP were inversely correlated with polyphenol excretion. ${ }^{19}$ Clinical-control examinations were performed as part of the same project. In some individuals, the diet was enriched with polyphenols by adding olive oil or nuts. After a year, in individuals with dietary intervention, a significant increase was observed in urinary polyphenols and serum nitric oxide, which was associated with a decrease in SBP and DBP. ${ }^{33}$

It should be emphasized that coffee is the main source of DTAP and DPI in the Polish population (including in individuals with AH). Coffee provides not only antioxidants but also caffeine, which has been reported to be linked with $\mathrm{AH}$, vascular resistance and endothelial dysfunction. ${ }^{34}$ On the other hand, as indicated by meta-analysis, in individuals with $\mathrm{AH}$, caffeine increases arterial blood pressure for only $3 \mathrm{~h}$, and no relationship has been confirmed between long-term coffee drinking and elevated $\mathrm{AH}$ or increased risk of CVD in AH patients. ${ }^{35}$ However, a study involving Kraków residents revealed that the risk of $\mathrm{AH}$ was lower in individuals declaring moderate consumption of coffee (3-4 cups/daily), and that only higher coffee intake did not protect against $\mathrm{AH} .{ }^{36}$

Considerable quantities of the bioactive substances analyzed in the current study were also obtained from tea. According to the available data, tea reduces arterial blood pressure. ${ }^{17,37}$ Unfortunately, the data was obtained from studies performed on a very small number of patients in a short period of time, which does not warrant conclusions regarding the long-term advantages of drinking large amounts of tea. ${ }^{17}$

Considering the inconclusive data on the effect of coffee and tea on $\mathrm{AH}$, it seems that the consumption of fruit and vegetables as the source of DTAP and DPI would be more beneficial for the Polish population.

Some respondents involved in the WOBASZ II took dietary supplements, an additional source of antioxidant potential, which were not taken into consideration in the analysis. However, the estimated involvement of study participants enriching their diet with vitamins and minerals was $12.3 \%$ and $15.7 \%$, respectively, in the group with and without $\mathrm{AH}$, and was not statistically differentiated (unpublished data). Therefore, it seems that the supplementation could not significantly modify the relationship between DTAP, DPI and AH.

The advantages of the presented study include: - results based on a representative sample of the adult 
Polish population, in a large number, with the use of standardized methods;

- assessment of individual dietary habits, recommended for the determination of the relationship between nutrition and health in epidemiological studies;

- measurement of the antioxidant potential and polyphenols in reconstituted food samples typical of the Polish market, taking into account culinary processing;

- the use of databases obtained from other countries generates errors due to the lack of regional dishes and because bioactive substances are determined in products from other climate and soil zones. However, culinary processes differently affect both the antioxidant potential and polyphenol content.

\section{Limitations of the study}

The limitations of the current study are as follows: - not very high responsiveness of the respondents in the WOBASZ II study is typical of other currently performed European epidemiological studies. This problem was discussed in previous WOBASZ-related publications. ${ }^{21,38}$ Additionally, statistical analyses were performed, confirming the similarity of distribution of people in age groups throughout the Polish population and in the study sample, which indicates the representativeness of the WOBASZ II study;

- arterial blood pressure was taken 3 times, but only during 1 visit;

- single assessment of dietary habits by means of 24-hourrecall is acceptable in large epidemiological studies, but its repetition could likely reduce the inter-individual variation of nutrition.

\section{Conclusions}

The intake of food with high antioxidant potential and rich in polyphenols was associated, slightly but independently of other factors, with a lower chance of hypertension in the adult Polish population. Higher DTAP (by $1 \mathrm{mmol} /$ day) or higher DPI (by $100 \mathrm{mg} /$ day) had reduced the odds of AH by approx. 1-2\%, even after correcting for confounding variables.

Coffee and tea were the basic dietary sources of the antioxidants studied, irrespective of sex and $\mathrm{AH}$. Taking into consideration the inconclusive data concerning the effects of these beverages on $\mathrm{AH}$, vegetables and fruit should be recommended as a more beneficial source of DTAP and DPI for the Polish population.

The results of the project can help formulate recommendations concerning polyphenol content and antioxidant potential of a daily food ration.

\section{References}

1. Sharma R. Polyphenols in health and disease. Practice and mechanisms of benefits. In: Watson RR, Preedy VR, Zibadi S. eds. Polyphenols in Human Health and Disease. Tokyo, Japan: Elsevier; 2014:757-778.

2. Medina-Remón A, Tresserra-Rimbau A, Valderas-MartinezP, Estruch R, Lamuela-Raventos RM. Polyphenol consumption and blood pressure. In: Watson RR, Preedy VR, Zibadi S. eds. Polyphenols in Human Health and Disease. Tokyo, Japan: Elsevier; 2014:971-987.

3. Pandey KB, Rizvi SI. Plant polyphenols as dietary antioxidants in human health and disease. Oxid Med Cell Longev. 2009;2(5):270-278.

4. Manach C, Mazur A, Scalbert A. Polyphenols and prevention of cardiovascular diseases. Curr Opin Lipidol. 2005;16(1):77-84.

5. Andriantsitohaina R, Auger C, Chataigneau T, et al. Molecular mechanisms of the cardiovascular protective effects of polyphenols. Br J Nutr. 2012;108(9):1532-1549.

6. Chong MF, Macdonald R, Lovegrove JA. Fruit polyphenols and CVD risk: A review of human intervention studies. Br J Nutr. 2010;104 (Suppl 3):S28-39.

7. Rautiainen S, Serafini M, Morgenstern R, Prior RL, Wolk A. The validity and reproducibility of food-frequency questionnaire-based total antioxidant capacity estimates in Swedish women. Am J Clin Nutr. 2008;87(5):1247-1253.

8. Agudo A, Cabrera L, Amiano P, et al. Fruit and vegetable intakes, dietary antioxidant nutrients, and total mortality in Spanish adults: Findings from the Spanish cohort of the European Prospective Investigation into Cancer and Nutrition (EPIC-Spain). Am J Clin Nutr. 2007; 85(6):1634-1642.

9. Dilis V, Trichopoulou A. Antioxidant intakes and food sources in Greek adults. J Nutr. 2010;140(7):1274-1279.

10. Tresserra-Rimbau A, Medina-Remón A, Pérez-Jiménez J, et al. Dietary intake and major food sources of polyphenols in a Spanish population at high cardiovascular risk: The PREDIMED study. Nutr Metab Cardiovasc Dis. 2013;23(10):953-959.

11. Ilow R, Regulska-Ilow B, Misiewicz D, Różańska D, Kowalisko A, Biernat J. Całkowity potencjał antyoksydacyjny wybranych produktów spożywanych przez 50-letnich mieszkańców Wrocławia w 2008 roku. Bromat Chem Toksykol. 2012;45(3):989-994.

12. Taguchi C, Fukushima Y, Kishimoto Y, et al. Estimated dietary polyphenol intake and major food and beverage sources among elderly Japanese. Nutrients 2015:7(12):10269-10281.

13. Ovaskainen ML, Törrönen R, Koponen JM, et al. Dietary intake and major food sources of polyphenols in Finnish adults. J Nutr. 2008; 138(3):562-566.

14. Ilow R, Regulska-Ilow B, Różańska D, Tangermann S, Grajeta H. Oszacowanie całkowitego potencjału antyoksydacyjnego wybranych produktów spożywanych przez studentów Akademii Medycznej we Wrocławiu w latach 2005-2007. Bromat Chem Toksykol. 2012;45(3): 995-1000.

15. Grosso G, Stepaniak U, Topór-Mądry R, Szafraniec K, Pająk A. Estimated dietary intake and major food sources of polyphenols in the Polish arm of the HAPIEE study. Nutrition 2014;30(11-12):1398-1403.

16. Miranda AM, Steluti J, Fisberg RM, Marchioni DM. Association between polyphenol intake and hypertension in adults and older adults: A population-based study in Brazil. PLoS One 2016;11(10):e0165791.

17. Hügel HM, Jackson N, May B, Zhang AL, Xue CC. Polyphenol protection and treatment of hypertension. Phytomedicine 2016;23(2):220-231.

18. Medina-Remón A, Estruch $R$, Tresserra-Rimbau A Vallverdú-Queralt A, Lamuela-Raventos RM. The effect of polyphenol consumption on blood pressure. Mini Rev Med Chem. 2013;13(8):1137-1149.

19. Medina-Remón A, Zamora-Ros R, Rotchés-Ribalta M, et al; PREDIMED Study Investigators. Total polyphenol excretion and blood pressure in subjects at high cardiovascular risk. Nutr Metab Cardiovasc Dis. 2011;21(5):323-331.

20. Niklas A, Flotyńska A, Puch-Walczak A, et al. Prevalence, awareness, treatment and control of hypertension in the adult Polish population - Multi-center National Population Health Examination Surveys - WOBASZ studies. Arch Med Sci. 2018;14(5):951-961.

21. Drygas W, Niklas AA, Piwońska A, et al. Multi-center National Population Health Examination Survey (WOBASZ II study): Assumptions, methods and implementation. Kardiol Pol. 2016;74(7):681-690. 
22. Różańska D, Regulska-Ilow B, llow R. Wpływ wybranych procesów kulinarnych na potencjał antyoksydacyjny i zawartość polifenoli w żywności. Probl Hig Epidemiol. 2014;95:215-222.

23. Benzie IF, Strain JJ. The ferric reducing ability of plasma (FRAP) as a measure of "antioxidant power": The FRAP assay. Anal Biochem. 1996;239(1):70-76.

24. Singleton VL, Rossi JA. Colorimetry of total phenolics with phosphomolybdic-phosphotungstic acid reagents. Amer J Enol Viticult. 1965; 16:144-158.

25. Carlsen $\mathrm{MH}$, Halvorsen $\mathrm{BL}$, Holte $\mathrm{K}$, et al. The total antioxidant content of more than 3100 foods, beverages, spices, herbs and supplements used worldwide. Nutr J. 2010;9(3):1-11.

26. Neveu V, Perez-Jiménez J, Vos F, et al. Phenol-Explorer: An online comprehensive database on polyphenol contents in foods. Database (Oxford). 2010; bap024: doi:10.1093/database/bap024

27. Zujko ME, Witkowska AM, Górska M, Wilk J, Krętowski A. Reduced intake of dietary antioxidants can impair antioxidant status in type 2 diabetes patients. Pol Arch Med Wewn. 2014;124(11):599-607.

28. Priori RL, Cao JA, Shukitt-Hale B. Can foods forestall aging? Some with high antioxidant activity appear to aid memory. AgResearch Magazine. 1999;47:15-17. https://agresearchmag.ars.usda.gov/1999/feb/ aging

29. Russnes KM, Möller E, Wilson KM, et al. Total antioxidant intake and prostate cancer in the Cancer of the Prostate in Sweden (CAPS) study: A case control study. BMC Cancer. 2016;16:438.

30. Perez-Jimenez J, Fezeu L, Touvier M, et al. Dietary intake of 337 polyphenols in French adults. Am J Clin Nutr. 2011;93(6):1220-1228.
31. Zujko ME, Witkowska AM, Waśkiewicz A, Mirończuk-Chodakowska I. Dietary antioxidant and flavonoid intakes are reduced in the elderly. Oxid Med Cell Longev. 2015;2015:843173.

32. Beg M, Sharma V, Akhtar N, Guta A, Mohd J. Role of antioxidants in hypertension. JIACM. 2011;12(2):122-127.

33. Medina-Remón A, Tresserra-Rimbau A, Pons A, et al; PREDIMED Study Investigators. Effects of total dietary polyphenols on plasma nitric oxide and blood pressure in a high cardiovascular risk cohort. The PREDIMED randomized trial. Nutr Metab Cardiovasc Dis. 2015; 25(1):60-67.

34. Di Castelnuovo A, Giuseppe R, lacoviello L, Gaetano G. Consumption of cocoa, tea and coffee and risk of cardiovascular disease. Eur J Intern Med. 2012;23(1):15-25.

35. Mesas AE, Leon-Muñoz LM, Rodriguez-Artalejo F, Lopez-Garcia E. The effect of coffee on blood pressure and cardiovascular disease in hypertensive individuals: A systematic review and meta-analysis. Am J Clin Nutr. 2011;94(4):1113-1126.

36. Grosso G, Stepaniak U, Polak M, et al. Coffee consumption and risk of hypertension in the Polish arm of the HAPIEE cohort study. Eur J Clin Nutr. 2016;70(1):109-115.

37. Turek I, Kozińska J, Drygas W. Zielona herbata jako czynnik protekcyjny w profilaktyce i leczeniu wybranych chorób serca i naczyń. Kardiol Pol. 2012;70(8):848-852.

38. Pająk A, Szafraniec K, Polak M, et al. Changes in the prevalence, treatment, and control of hypercholesterolemia and other dyslipidemias over 10 years in Poland: The WOBASZ study. Pol Arch Med Wewn. 2016; 126(9):642-652. 